\title{
Biohydro-optical classification of the northwestern Indian Ocean
}

\author{
John C. Brock ${ }^{1, *}$, Shubha Sathyendranath ${ }^{2}$, Trevor Platt ${ }^{2}$ \\ 'NOAA Coastal Services Center, 2234 South Hobson Avenue, Charleston, South Carolina 29405-2413, USA \\ ${ }^{2}$ Biological Oceanography Division, Bedford Institute of Oceanography, Box 1006, Dartmouth, Nova Scotia B2Y 4A2, Canada
}

\begin{abstract}
An approach to a partial solution to the general problem of defining biogeochemical provinces for the accurate estimation of global-ocean primary production and realistic structuring of epipelagic plankton ecosystem models is presented for the northwestern Indian Ocean. This is accomplished through use of a new technique, biohydro-optical classification, that applies a rudimentary submarine light budget incorporating climatologies of incident light, mixed-layer thickness, and chlorophyll to recognize fundamental modes of tropical plankton ecosystems. The 3 types of biohydro-optical classes found in the Arabian Sea, Typical Tropical, Mixed-Layer Bloom, and Transitional, are shown to evolve through the spring intermonsoon (March through May), summer southwest monsoon (June through August), and fall intermonsoon (September through November) under climatic forcing and in response to the resulting biological variability. Virtually all of the open Arabian Sea is within the Typical Tropical Class at the close of the spring intermonsoon. This class type is intended to identify the epipelagic plankton ecosystem mode associated with tropical regions containing a deep chlorophyll maximum (DCM) maintained by active algal growth, and a light-rich, oligotrophic shallow zone containing a phytoplankton association which depends largely upon regenerated nutrients. At the close of the southwest monsoon in August, a Mixed-Layer Bloom Province covers much of the northern Arabian Sea. This province class corresponds to the ecosystem mode represented by tropical regions undergoing marginal or mid-ocean upwelling and greatly simplifies regional extrapolation of the local primary production algorithm. At the onset of the fall intermonsoon, the Mixed-Layer Bloom Province in the northern and western Arabian Sea is superseded by a Transitional Province, which persists through the fall intermonsoon. We interpret the upper layer of the fall intermonsoon Transitional Province in the Arabian Sea as a special case of the shallow regenerative plankton ecosystem of oligotrophic ocean areas, where rates of zooplankton-driven nutrient regeneration and recycled production, key processes in the upper layer of the classic 2-layer euphotic zone of oligotrophic low-latitude oceans, reach extreme values.
\end{abstract}

KEY WORDS: Indian Ocean · Primary production · Biogeochemistry · Satellite remote-sensing Modeling $\cdot$ Phytoplankton ecosystems

\section{INTRODUCTION}

Recent progress towards the estimation of globalocean primary production from satellite observations has underscored the need to define seasonally dynamic, biogeochemical provinces for the world ocean (Platt \& Sathyendranath 1988, 1993a, b). Models of primary production based on algal physiology, which incorporate variation in the light-photosynthesis

•E-mail: jbrock@csc.noaa.gov relationship due to light history, temperature, nutrients, and the possibility of vertical heterogeneity in phytoplankton biomass, are inherently superior to empirical approaches lacking a mechanistic foundation. However, in the absence of valid biogeochemical provinces to guide their parameterization, it is not possible to implement appropriately or test deterministic primary production models using global compilations of in situ measurements. Robust methods to classify the world ocean synoptically into biogeochemically similar provinces are widely recognized as a requirement for estimation of global-ocean primary production (Eppley 
et al. 1985, Platt \& Sathyendranath 1988, Platt et al. 1991, Lewis 1992). Biogeochemical partitioning of the world ocean would also identify the region-specific seasonal switching of upper-ocean ecosystem modes, and thereby allow for more realistic and efficient models of the overall epipelagic plankton ecosystem (Longhurst \& Harrison 1989, Sarmiento et al. 1993, Longhurst et al. 1995).

We regard the definition of biogeochemical provinces as a means to parameterize the most rigorous oceanic primary-production models, those based on algal physiology. Estimates of global oceanic primary production require a method of defining biogeochemical provinces that is synoptic and evolves seasonally and independently within diverse regions. Ultimately, the province boundaries must represent significant variation in the parameters of the photosynthesis-light curve and in the likelihood of significant production within a deep chlorophyll maximum (DCM) beyond the view of surface, ocean-color remote sensing.

The goal of this paper is to present for the Arabian Sea basin an approach to a partial solution to the general problem of defining biogeochemical provinces by the application of a new technique, biohydro-optical classification, which is a dynamic method to infer the sites and ecological mode of significant primary production within tropical ocean basins. The primary objectives are to:

(1) introduce a method of biohydro-optical classification which identifies tropical ocean zones where significant primary production is likely to occur either in the mixed layer or in a DCM layer, and which reflects whether primary production is dominantly lightlimited or light-saturated, and

(2) present and interpret biohydro-optical classification maps of the northwestern Indian Ocean for months within the northeast monsoon (December through February), spring intermonsoon (March through May), summer southwest monsoon (June through August), and fall intermonsoon (September through November) seasons through comparison to historical in situ biogeochemical observations.

\section{BACKGROUND}

The fundamental basis for partitioning the world ocean into discrete provinces is that rates of key ecophysiological and biogeochemical processes are ultimately controlled by physical forcing (Platt et al. 1995). Nutrient fluxes to the euphotic zone, the rate of vertical mixing, and the stratification of the water column affect phytoplankton production and are driven by physical processes. These physical processes, together with loss terms such as sinking and grazing (Longhurst
\& Williams 1979, Banse 1992), are significant controls on the ambient plankton species assemblage (Frost 1980), phytoplankton photoadaptation, and the vertical distribution of photosynthetic pigments. In a recent estimate of global-ocean primary production from satellite radiometer observations, Longhurst et al. (1995) introduced a hierarchical classification scheme, which recognized 4 primary domains of the global pelagic ecosystem based on physical forcing (Polar, Westerlies, Trade Winds, and Coastal), which are further split into 57 biogeochemical provinces.

Biogeochemical provinces based on broad patterns of physical forcing of the ocean have a solid theoretical underpinning, but implementations have, thus far, yielded province maps that lack generalized seasonality and, further, do not reflect spatial or interannual variability from accepted climatological forcing patterns (Platt \& Sathyendranath 1988, 1995, Mueller \& Lange 1989, Longhurst et al. 1995, Platt et al. 1995). Some progress has been achieved towards provincespecific rules to predict vertical profiles of irradiance attenuation (Mueller \& Lange 1989) or column-integrated pigment concentration and its vertical distribution (Morel \& Berthon 1989), based on the surface pigment or the surface diffuse attenuation coefficient, both of which may be estimated from remotely sensed ocean color.

To be truly 'dynamic', province boundaries, and the province-specific rules that guide estimation of properties within provinces, should be determined from synoptic, remotely sensed data or based on hydrographic simulations from ocean models. In other words, near real-time geophysical fields derived from satellite observations, or calculated from models forced by these fields, are required for the dynamic partitioning of the ocean. Relevant modeled or synoptically observed variables include surface irradiance, the concentrations of upper-ocean constituents that modify the submarine light field through absorption, scattering, or use in photosynthesis, sea-surface temperature, mixed-layer depth and gross pycnocline structure relative to local nutrient and light profiles, or proxies for phenomena that are uniquely associated with particular provinces, such as zooplankton blooms and DCMs.

Although previously proposed methods of province delineation are not dynamic because they reveal only ocean regions whose climatological annual cycle of physical forcing is distinct, some progress towards the use of satellite observations in perceiving the shorttimescale evolution of ecosystem zonation has been achieved. In estimating the carbon fixation of the eastern Mediterranean based on Coastal Zone Color Scanner (CZCS) upper-ocean pigment concentration and a light-photosynthesis model, Antoine \& Morel (1995) used the general distribution of CZCS-derived surface 
algal pigment to define 5 provinces. In a procedure that closely parallels aspects of the biohydro-optical classification presented in this paper, Antoine \& Morel (1995) used a submarine light model and the Levitus (1982) mixed-layer depth climatology to infer the possibility of an actively photosynthesizing DCM at the base of the euphotic zone. Similarly, Mitchell et al. (1991) used CZCS 7 yr average pigment concentrations to reveal a meridional zonation in the Barents Sea ecosystem that was confirmed by physical-opticalbiological sampling with high vertical and horizontal resolution. Sathyendranath et al. (1991) used satellitederived sea-surface temperature and pigment concentration, along with bathymetry, to delineate provinces in the vicinity of Georges Bank.

\section{APPROACH}

Biohydro-optical classification seeks to determine the instantaneous spatial distribution of stratified euphotic zones in the tropical, subtropical, and temperate ocean, based only on variables that may either be predicted accurately by basin-scale models or synoptically observed in real time by satellite. In developing a biohydro-optical classification for the Arabian Sea, we first estimated the light reaching the sea surface on the 15th day of each month of the year (Bird 1984, Brock et al. 1993). We used a simple cloud-free model (Bird 1984) and corrected for cloudiness using the Max Planck Institute monthly cloudiness climatology. We then used the atlas of Hastenrath \& Greischar (1989) to define monthly mixed-layer thickness and generated a monthly climatology of mixed-layer phytoplankton biomass from CZCS observations (Feldman et al. 1989).

Our classification method assumes idealized Case I (Morel \& Prieur 1977) water in which only chlorophyll, regularly covarying gelbstoff, and seawater itself (Jerlov 1976, Smith \& Baker 1981) act to attenuate sunlight. Fhis approach attows us to estimate the-verticalattenuation coefficient for light directly from the chlorophyll concentration. This 2-component system is admittedly oversimplified, but it is probably reasonable for most of the open Arabian Sea throughout much of the year. Note that our method relies upon satellite observations of ocean color to determine levels of light attenuation above that caused by seawater alone. Accordingly, the method should be robust to a first approximation, even if the satellite chlorophyll estimate also reflects the presence of other sources of absorption in the water column.

We next classified the Arabian Sea for each month on a $1^{\circ}$ grid, by applying a rudimentary submarine light budget that uses the climatologies of incident light, mixed-layer thickness, and chlorophyll to move through a decision tree (Fig. 1). The classifier first examines the propagation of light in the mixed-layer using the submarine light model of Sathyendranath \& Platt (1988), with the initial branching of the decision tree dependent on whether phytoplankton or seawater (Jerlov 1976, Smith \& Baker 1981) dominates the attenuation of light. The submarine light model is next used to examine the fraction of surface light remaining at the base of the mixed layer, and a second classification branching depends on whether or not the euphotic

Fig. 1. Decision tree for the biohydrooptical classification of the Arabian Sea

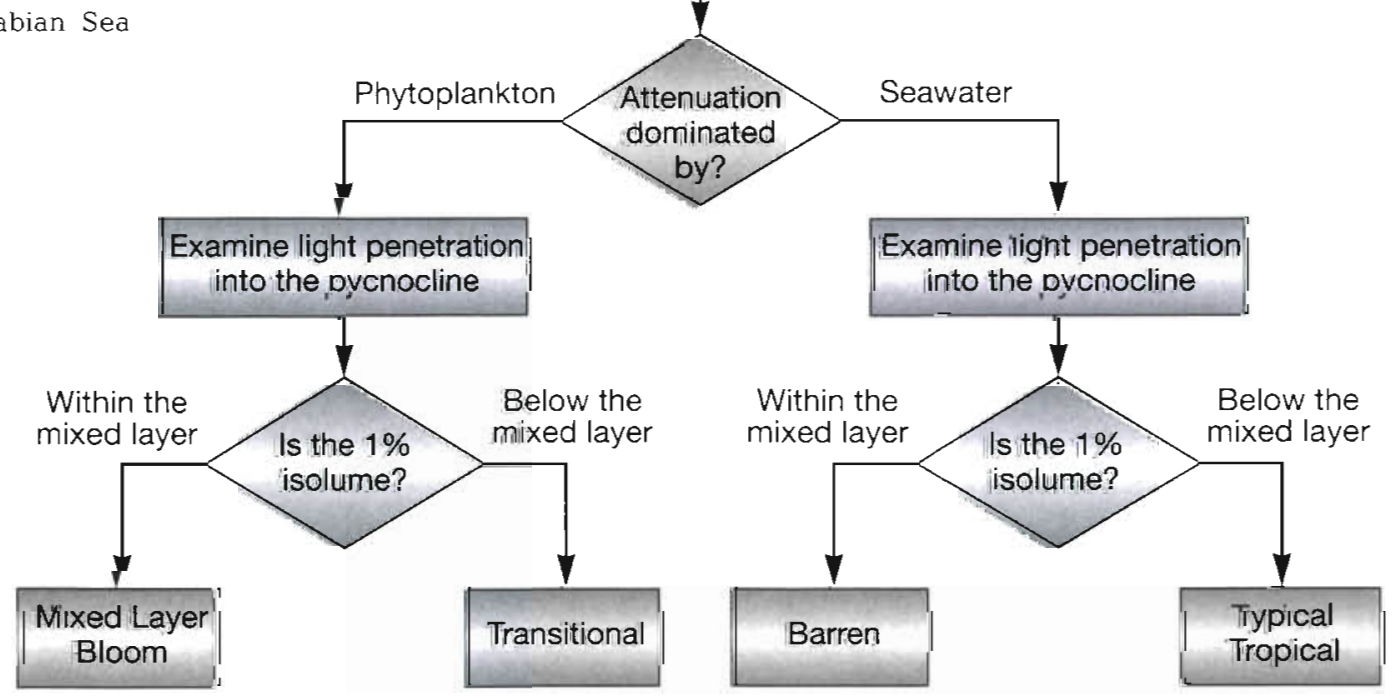


zone is contained wholly within the mixed layer. Alternatively, the $1 \%$ isolume, which is often used to define the depth of the euphotic zone and which corresponds roughly to the compensation depth at which photosynthesis balances respiration, may lie below the top of the pycnocline, which typically coincides with a sharp nutricline (Wyrtki 1971) in the Arabian Sea. This pair of classifier decisions yields 4 possible classes, including Mixed-Layer Bloom and Typical Tropical (Herbland \& Voituriez 1979), which represent opposite modes for the plankton ecosystem of a tropical ocean, and 2 others called Transitional and Barren (in this paper, the term 'Province' denotes a significant cluster of classified grid cells within a given 'Class').

In ocean regions within the Typical Tropical Class, light within the mixed layer is attenuated mainly by seawater, and the euphotic zone is expected to extend into the pycnocline. This condition matches that found typically within stratified, unperturbed tropical and subtropical open ocean regions. The opposite and most eutrophic condition is categorized as the Mixed-Layer Bloom Class, within which mixed-layer light is mainly attenuated by phytoplankton and its covarying degradation products, and the base of the euphotic zone is modeled to be shallower than the mixed-layer depth.

Physical processes, such as upwelling or mixing, that bring nutrients into the mixed layer and stimulate phytoplankton blooms where integrated, mixed-layer light levels are sufficient also cause the breakdown of the Typical Tropical Class and a transition to the Mixed-Layer Bloom Class, whose margins are generally fringed by a narrow band categorized within the Transitional Class. This third class type, in which phytoplankton biomass and covarying degradation products dominate mixed-layer light attenuation, while the $1 \%$ isolume still resides within the pycnocline, is typically overridden by the Mixed-Layer Bloom Class during bloom inception, as shallow phytoplankton concentrations and light attenuation increase. The fourth and most oligotrophic category within the classification is the Barren Class, with seawater-dominated, mixed-layer light attenuation and a euphotic zone wholly above the pycnoline. Given the high year-round levels of surface irradiance at its tropical and subtropical latitudes, the Barren Class occurs only rarely in the Arabian Sea.

\section{Basis for biohydro-optical classification of the mixed layer}

In all 4 biohydro-optical class types, the decisionrule used in classifying the mixed upper layer is derived from the bio-optical classification methods presented by Jerlov (1976), Smith \& Baker (1978a, b),
Baker \& Smith (1979), and Morel (1988). These methods utilize the diffuse attenuation coefficient for photosynthetically available irradiance, $K_{T}$, a 'quasi-inherent' (Baker \& Smith 1979) physical measure of the bio-optical state of ocean waters, which relates the remote-sensing signal to the biological status of natural waters. The coefficient $K_{\mathrm{T}}$ is strongly influenced by the chlorophyll-like phytoplankton pigment concentration $\left(C_{S A T}\right)$, which largely determines the waterleaving radiance observed by remote-sensing devices, and provides information on the portion of the downwelling irradiance attenuated by phytoplankton and thus available for photosynthesis. Given that both $K_{\mathrm{T}}$ and $C_{\text {SAT }}$ can be determined by satellite, and the attenuation due to pure seawater is a quasi-inherent optical property, it is possible to examine important surface variables of the marine ecosystem rapidly and repeatedly from space (Smith \& Baker 1978b).

The analysis of Lewis \& Kuring (1988), who derived climatological average fields of global-ocean transparency from historical Secchi disk measurements, rather than satellite observations, is an excellent example of the extrapolation of bio-optical characterization based on diffuse attenuation to large spatial scales. The global patterns of ocean transparency revealed by this analysis appear to match roughly the provinces defined based on physical forcing (Longhurst et al. 1995) in major coastal upwelling regions and the central gyres of the North Pacific and North Atlantic. Sharp boundaries in water clarity that migrate up to $1000 \mathrm{~km}$ seasonally mark the transitions between regions defined by Lewis \& Kuring (1988).

Our biohydro-optical classification adapts the general equations for the total spectral diffuse attenuation coefficient $K_{\mathrm{T}}(\lambda)$ (Smith \& Baker 1978a, Prieur \& Sathyendranath 1981), which have been further developed for Case I waters (Morel \& Prieur 1977, MoreI 1988, Platt \& Sathyendranath 1988) to implement the first decision in the classification

$$
K_{T}(\lambda)=K_{W}(\lambda)+K_{X}(\lambda)+K_{C}(\lambda)
$$

where $K_{\mathrm{T}}(\lambda)=$ total diffuse attenuation coefficient for spectral irradiance $\left(\mathrm{m}^{-1}\right), K_{\mathrm{w}}(\lambda)=$ diffuse spectral attenuation coefficient for clear ocean waters $\left(\mathrm{m}^{-1}\right), K_{X}(\lambda)=$ diffuse spectral attenuation coefficient for optically active substances other than chlorophyll-like pigments $\left(\mathrm{m}^{-1}\right)$, and $K_{C}(\lambda)=$ diffuse spectral attenuation coefficient for chlorophyll $a$ and phaeopigments to a depth of 1 attenuation length $\left(\mathrm{m}^{-1}\right)$, including attenuation coefficient due to gelbstoff which covaries with chlorophyll $a$. The CZCS satellite observations were used to estimate the concentration of chlorophyll $a$ and pheopigments in the first attenuation length $\left(C_{S A T}\right)$.

Our use of the spectral submarine light model of Sathyendranath \& Platt (1988) allows us to calculate 
estimates of the depth and wavelength averaged values for $K_{\mathrm{T}}(\lambda), K_{\mathrm{W}}(\lambda)$, and $K_{\mathrm{C}}(\lambda)$ for each $1^{\circ} \times 1^{\circ}$ grid cell.

Under the assumption of Case I water, the term $K_{X}(\lambda)$ is ignored, allowing the direct comparison of the wavelength-integrated spectral diffuse attenuation caused by either pure seawater or phytoplankton through the ratio:

$$
K_{W} / K_{C}
$$

A value greater than 1 for this ratio implies that the grid cell being classified is either in the Typical Tropical or Barren Class; otherwise it will be assigned to the Mixed-Layer Bloom or Transitional Class, dependent upon the modeled hydrographic position of the $1 \%$ isolume

Our bio-optical classification of the mixed layer is subject to errors in the retrieval of chlorophyll $a$ and covarying phaeopigments by the CZCS data acquisition and processing system. Although an examination of the validity of this assumption of Case I water for all of the Arabian Sea is beyond the scope of this paper, we did investigate the possibility that a DCM influences the remote-sensing reflectance measured by satellite (Sathyendranath \& Platt 1989). Given that $90 \%$ or more of the irradiance reflected diffusely out of the ocean emanates from the first optical depth (Gordon \& McCluney 1975), using climatological mixedlayer depth and $C_{\text {SAT }}$ we calculated the optical thickness of the Arabian Sea mixed layer for each month of the year. This analysis revealed that the mixed layer is optically thinnest off the Somali coast in November at approximately $5^{\circ} \mathrm{N}, 55^{\circ} \mathrm{E}$ (Fig. 2), but at no time does it

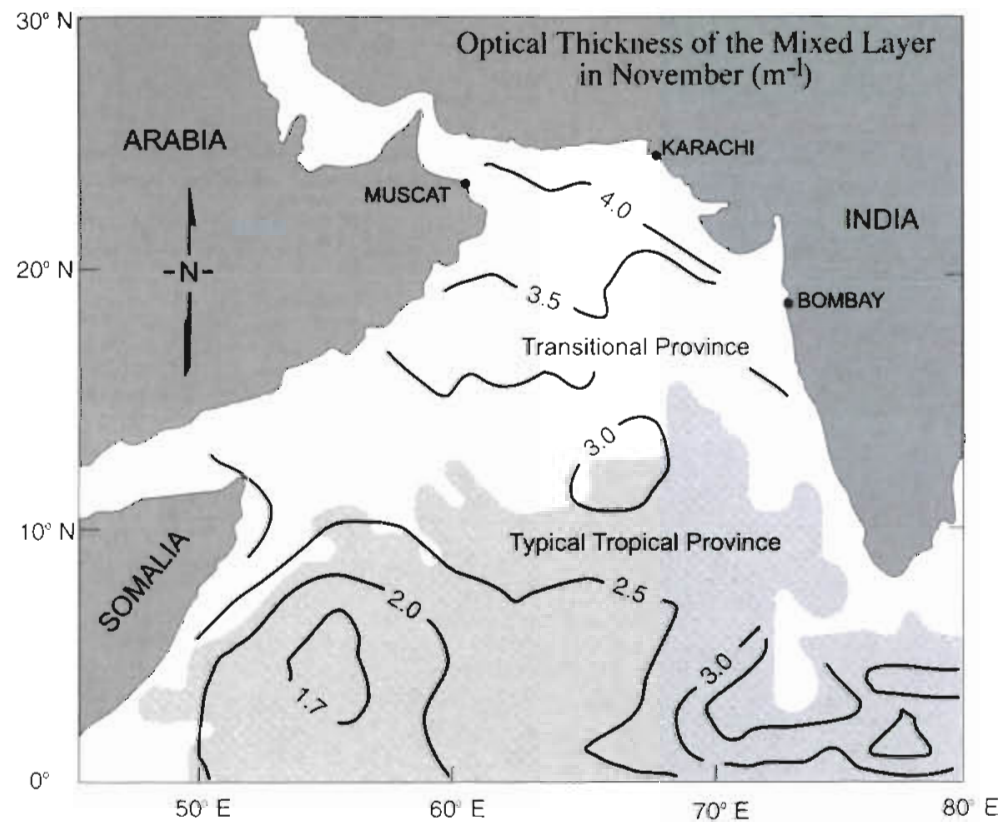

Fig. 2. Modeled optical thickness of the mixed layer in November thin to less than 1 attenuation depth. Note that this procedure suggests a means of identifying within $C_{S A T}$ fields regions of erroneous pigment retrieval due to the influence of a DCM on the remote-sensing signal. Such locations would be probable within closures of the mixed-layer 1 optical depth isopleth. However, due to the potential for additional light absorption, should a DCM be present within the first attenuation length, the resulting erroneous chlorophyll retrieval may yield an incorrectly large value for mixed-layer optical thickness and confuse the procedure. Accordingly, closure of mixed-layer optical depth contours at lows near 1 optical depth should reveal those regions most suspect for DCM influence on satellite-based chlorophyll estimates.

\section{Basis for biohydro-optical classification of the pycnocline}

The second and final decision in our classification method captures whether or not any portion of the upper pycnocline is contained within the euphotic zone. In our procedure, the base of the euphotic zone is set equal to the $1 \%$ isolume, assumed to be the compensation depth, and thus the second decision evaluates whether significant net primary production is possible in a lower, potentially nutrient-rich layer of the euphotic zone. We have made the simplifying assumptions for the Arabian Sea that the density profile is a function of the vertical temperature gradient, and that the pycnocline and nutricline occur within an equivalent depth range (Ryther et al. 1966, Brock et al. 1992)

Much previous work (Yentsch 1965, Venrick et al. 1973, Gieskes et al. 1978, Hayward et al. 1983) has demonstrated that the DCM is a global feature which occurs commonly in the tropical and subtropical ocean, is found seasonally in the temperate ocean, responds to the regional hydrographic and light structure of the water column, and has continuity across much of the Earth's surface (Longhurst \& Harrison 1989). Given that in stable oceanographic regimes, a DCM usually occurs low in the euphotic zone, in the vicinity of a density discontinuity at light levels between 0.1 and $10 \%$ of the surface irradiance (Longhurst \& Harrison 1989), for simplicity the base of the euphotic zone is defined as the $1 \%$ isolume in our procedure. Building on the comparative study of chlorophyll profiles from different regions and the genetic classification of DCM types presented by Cullen (1982), Longhurst \& Harrison (1989) distin- 
guished 5 primary regimes marked by unique seasonal cycles and formation mechanisms for chlorophyll profiles and, especially, their DCMs. These regimes are separable based on the occurrence of salient modes of the plankton ecosystem, driven by unique climatic conditions and physical forcing, and keyed to the means of DCM formation and maintenance. Biohydro-optical classification seeks to recognize in space and time conditions appropriate for the occurrence of several of these unique ecosystem modes, associated with the primary euphotic zone regimes listed by Longhurst \& Harrison (1989): (1) tropical regions with a permanent pycnocline; (2) regions undergoing pycnocline deepening through deep winter mixing or geostrophic adjustment; and (3) tropical regions impacted by marginal or mid-ocean upwelling.

\section{RESULTS}

At the close of the northeast monsoon in February, all of the northwestern Arabian Sea falls into the Mixed-Layer Bloom Class, separated from Typical Tropical conditions to the south by a Transitional Province occupying a several-hundred-kilometer-wide swath that exists in the Gulf of Aden and extends from Somalia to northern India (Fig. 3A). During the spring intermonsoon, weak winds and high insolation (Hastenrath \& Lamb $1979 a$, b) drive virtually all of the Arabian Sea towards the Typical Tropical Class. In March (Fig. 3B) this occurrence of a short-lived Mixed-Layer Bloom Province senesces, leaving a broad Transitional Province in its wake, while the Typical Tropical Province begins to advance northward. In April (Fig. 3C) the Transitional Province in the northern Arabian Sea
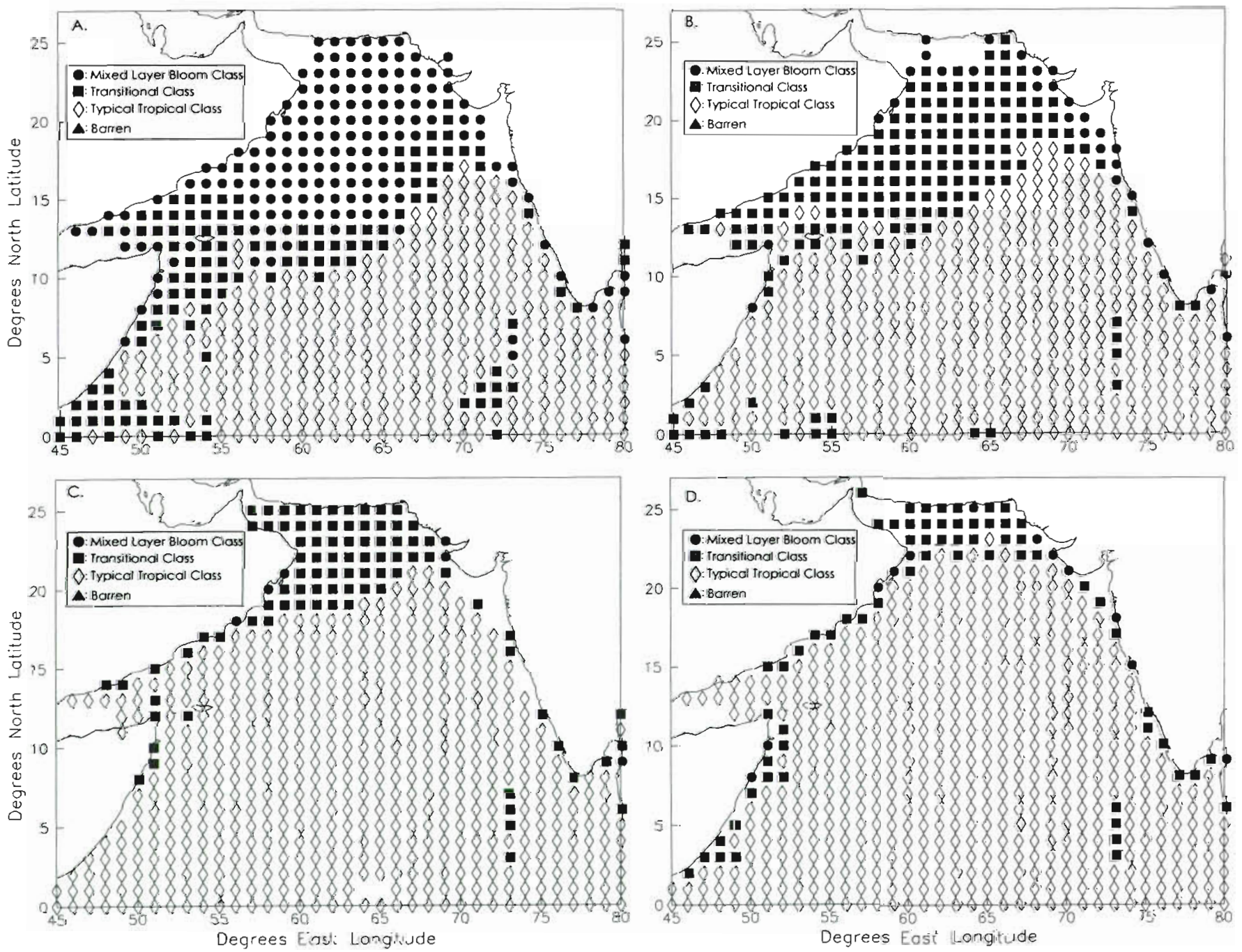

Fig. 3. Monthly biohydro-optical classification maps for the late northeast monsoon and the spring intermonsoon, including (A) February, (B) March, (C) April, and (D) May 

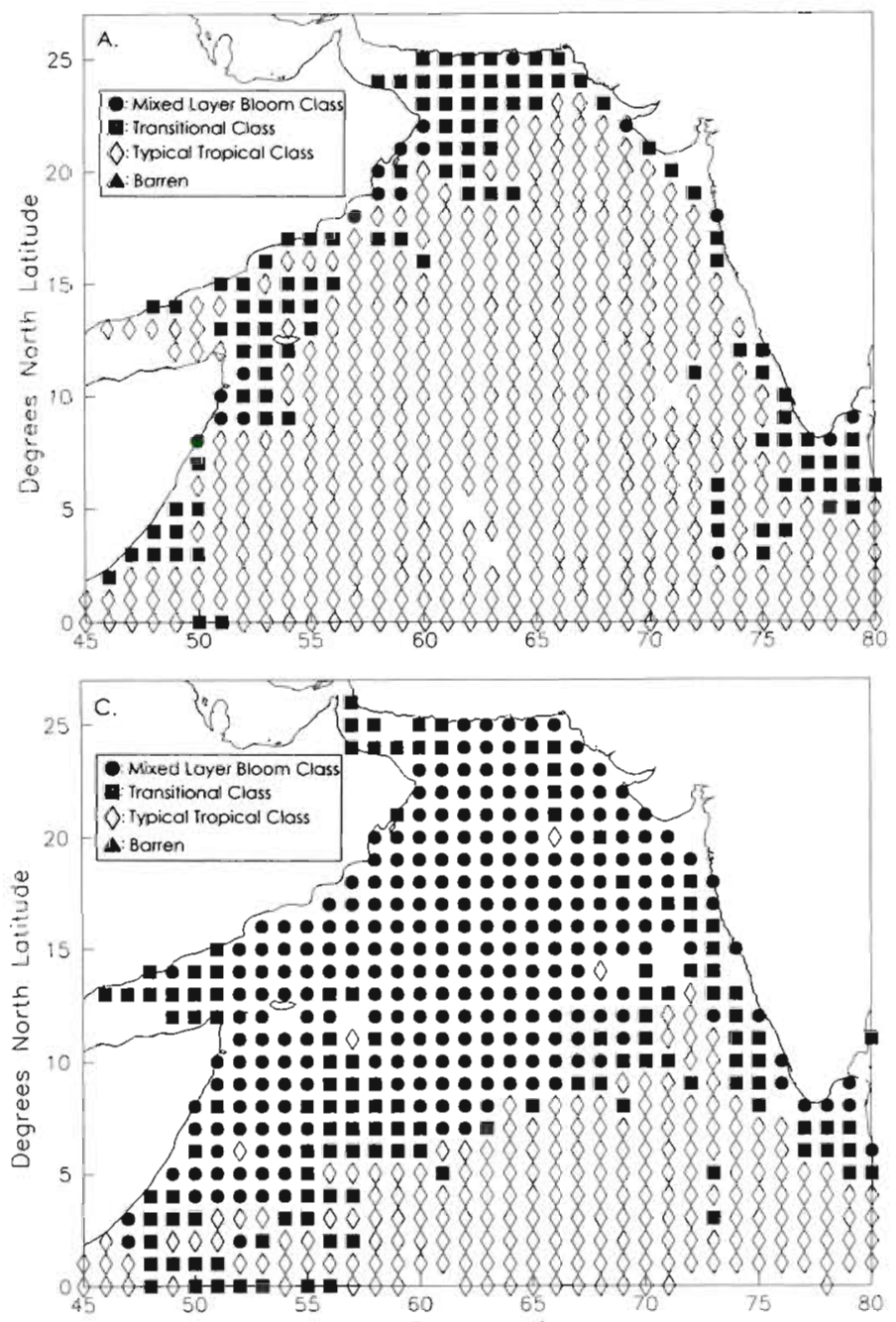

Degrees East Longitude

retreats towards the Gulf of Oman, so that by May it is mainly found in the open Arabian Sea north of $20^{\circ} \mathrm{N}$. In May (Fig. 3D) at the close of the quiescent spring intermonsoon, almost all of the Arabian Sea other than the coastal fringe and the waters off the Maldives constitutes 1 continuous Typical Tropical Province. We believe that this point in the annual cycle represents a baseline, when the Arabian Sea most closely approximates its natural unperturbed 'typical tropical' status in the absence of monsoonal disruption.

In June, the first month of the southwest monsoon, the extensive Typical Tropical Province found in May begins to recede southeastward, as a fragmented Transitional Province begins to form along the coasts of Oman, Somalia, and in the Gulf of Aden (Fig. 4A). Persistent cloudiness in July impedes bio-optical classification of the northern Arabian Sea, but off Somalia the developing Transitional Province now extends roughly $800 \mathrm{~km}$ offshore, and appears to grade northeastward

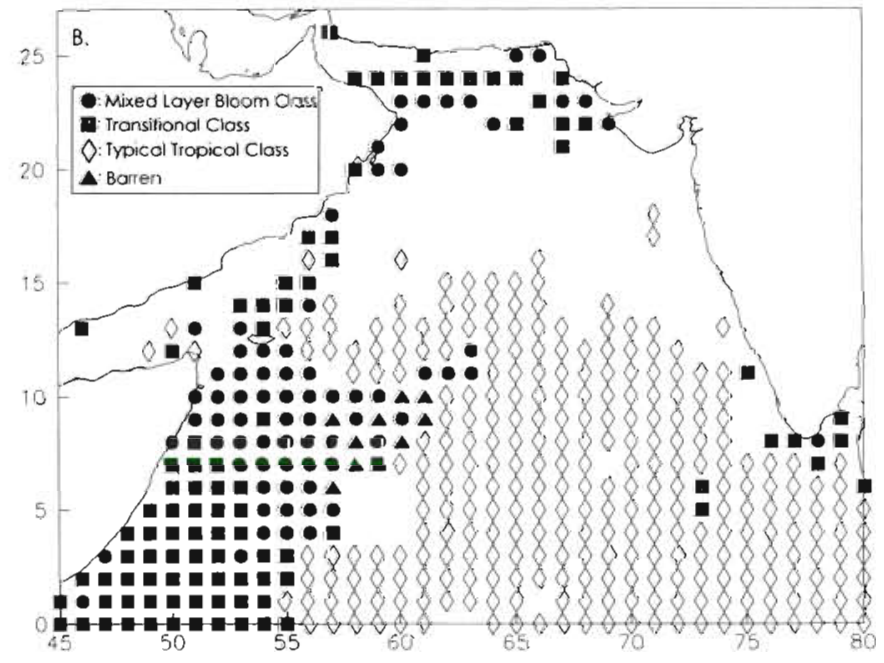

Fig. 4. Monthly biohydro-optical classification maps for the southwest monsoon, including (A) June, (B) July, and (C) August into a newly emerging Mixed-Layer Bloom Province. A rare occurrence of grid cells categorized as Barren Class appear in July centered about $10^{\circ} \mathrm{N}, 59^{\circ} \mathrm{E}$ at the transition from the Mixed-Layer Bloom to the Typical Tropical Province (Fig. 4B). In August at the close of the southwest monsoon, extremely monsoon-influenced conditions prevail (Fig. 4C), including a MixedLayer Bloom Province that covers much of the northern Arabian Sea north of about $10^{\circ} \mathrm{N}$. The Typical Tropical Province that covered nearly all of the Arabian Sea in May has receded southward, existing mainly to the south of this latitude, aside from scattered anomalous occurrences. Although patchy, the Transitional Class grid cells are again generally found to buffer the Mixed-Layer Bloom Province from the Typical Tropical Province.

In September at the start of the fall intermonsoon, the Mixed-Layer Bloom Province in the northern Arabian Sea has already begun to dissipate (Fig. 5A). The 

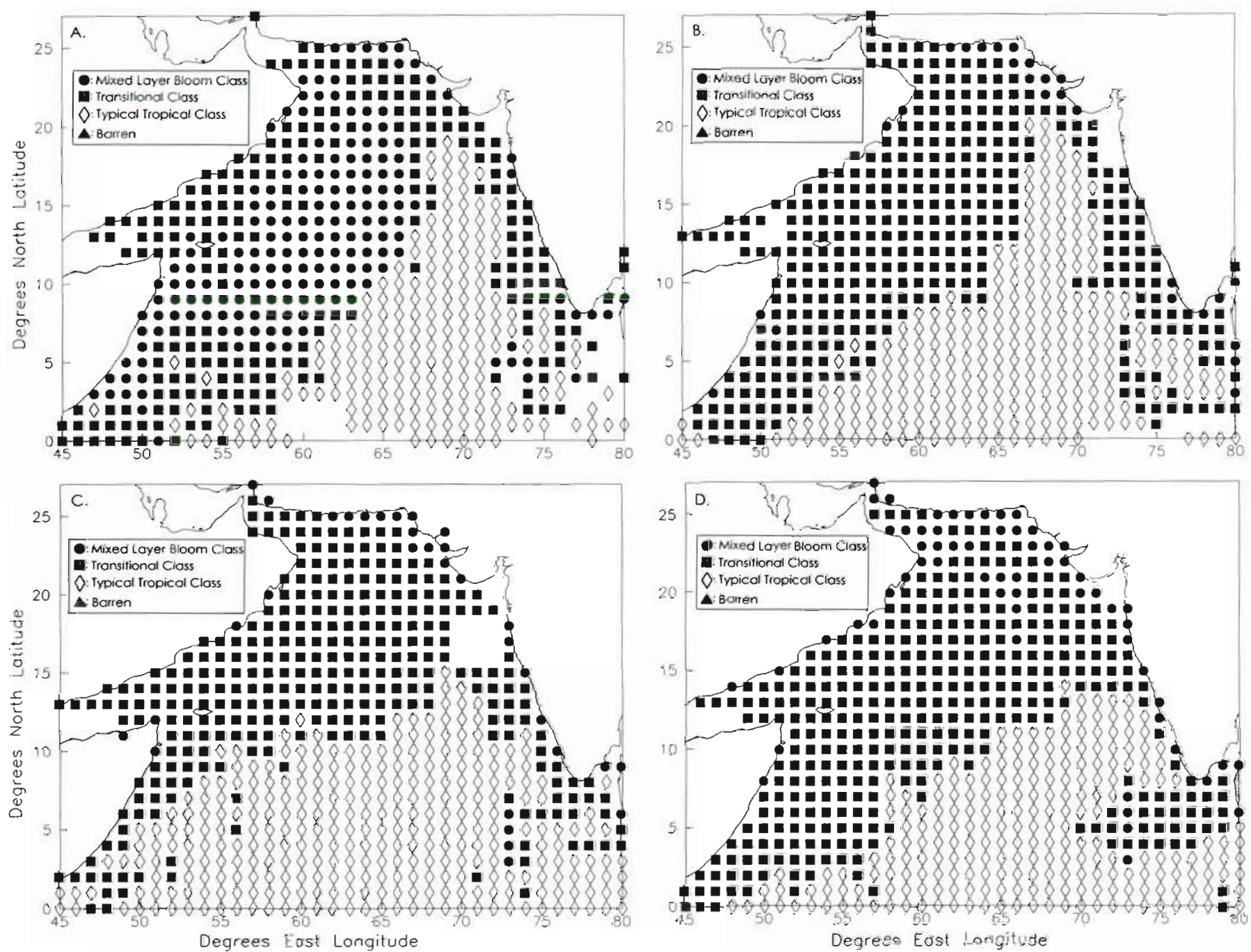

Fig. 5. Monthly biohydro-optical classification maps for the fall intermonsoon and the early northeast monsoon, including (A) September, (B) October, (C) November, and (D) December

southern Typical Tropical Province now extends north off the west coast of India to $20^{\circ} \mathrm{N}$, and off the coasts of northwest India, Pakistan, Oman, and Yemen, the August Mixed-Layer Bloom classification has reverted to the Transitional Class. The Mixed-Layer Bloom Province persists in the central Arabian Sea, centered about $13^{\circ} \mathrm{N}, 63^{\circ} \mathrm{E}$, and directly abutting the Typical Tropical Province to the southeast. The configuration of the Typical Tropical Province in October (Fig. 5B) is similar, but the Mixed-Layer Bloom Province in the central Arabian Sea has been replaced by the encroaching Transitional Province. Through November (Fig. 5C) and December (Fig. 5D) the Transitional Province in the western and northern Arabian Sea persists and expands slightly to the southeast, in spite of the approaching winter solstice and accompanying drop in surface insolation.

\section{DISCUSSION}

Plankton ecology of biohydro-optical classes

\section{Typical Tropical Class}

The Typical Tropical Class is intended to identify the plankton ecosystem mode associated with tropical regions with a permanent pycnocline. Dugdale \& Goering (1967) noted that in tropical and subtropical regions, a thermocline deep in the euphotic zone typically limits the upward eddy diffusion of nutrients, causing opposite vertical gradients in light and nutrients. Given that shallow phytoplankton usually keep pace with the cross-thermocline nutrient flux in unperturbed low-latitude seas, a layered euphotic zone is widely observed, consisting of 2 layers: (1) an upper light-rich, low algal biomass layer where nutrients 
limit phytoplankton growth, and (2) a deeper zone of light-limited photosynthesis within the upper nitricline containing a DCM (Dugdale \& Goering 1967). Based on analysis of numerous shallow profiles acquired in the tropical Atlantic, Herbland \& Voituriez $(1977,1979)$ extended the concept of layered euphotic zones to define a Typical Tropical Structure (TTS), proposed as universal for quiescent tropical euphotic zone ecosystems. Among the common attributes of the TTS listed are: (1) a nitrate-depleted upper layer above a lightlimited lower layer; (2) roughly equivalent depths of the nitricline, oxycline, and DCM; (3) a photosynthesis peak in close association with the DCM; (4) close depth correlation between the thermocline and nitricline; and (5) an inverse relationship between depth and the peak value in the chlorophyll maximum (Herbland \& Voituriez 1979, Cullen 1982).

The Typical Tropical Class upper layer is an approximation of the light-rich, nutrient-limited oligotrophic shallow zone of the TTS, a physiological regime described by Eppley et al. (1973) as containing a phytaplankton association that receives light in excess, but which depends largely upon regenerated nutrients. Within our method of basin classification, this ecological mode of the mixed layer is recognized through the use of the satellite-derived concentration of phytoplankton pigments in the mixed layer, and previously suggested methods (Morel \& Prieur 1977, Smith \& Baker 1978a, Prieur \& Sathyendranath 1981, Morel 1988, Sathyendranath \& Platt 1988) for the bio-optical classification of natural waters. In the Typical Tropical Class, the potential for a DCM formed and maintained primarily as a result of enhanced primary production in the lower layer is inferred, based on the modeled downward penetration of the euphotic zone into the nitricline. Low seasonal variation allows for greater temporal uniformity of plankton processes in the tropics (Cushing 1981), resulting in vertical profiles that represent steady-state fluxes, and closely coupled biological and physical processes (Cullen 1982). A chlorophyll maximum near the nitricline at 1 to $10 \%$ of surface light levels either below or in close association with a primary production maximum is consistent with DCM maintenance through enhanced growth in the lower euphotic zone stratum and has been observed in the eastern tropical Atlantic (Herbland \& Voituriez 1977, 1979), the eastern tropical Pacific (Longhurst 1981. Marra et al. 1987), the north central Pacific (Small et al. 1987), the Gulf of Mexico (Hobson \& Lorenzen 1972) and the northwest Indian Ocean (Yentsch 1965, Karabashev \& Solov'yev 1978).

Longhurst \& Harrison (1989) generalized that in cases where the DCM occurs in the classic TTS at depths with sufficient nitrate and light for net algal growth, the DCM will represent an algal biomass max- imum, rather than vertical variation in the ratio of carbon to chlorophyll. These researchers documented the depth coincidence of the DCM, nutricline, and pycnocline in permanently stratified tropical waters and further hypothesized that in tropical oceans the decoupling of chlorophyll and algal biomass profiles is a function of DCM depth, which is geostrophically driven on a basin scale. On the eastern sides of tropical oceans, or at the close of the summer season at temperate latitudes with greater seasonality, the most mature TTS develops, with the $1 \%$ light depth deeper than the nutricline, and only partially shade-adapted algal cells.

We have used the high nitricline light level established by Longhurst \& Harrison (1989) as necessary for maintenance of a true TTS in our selection criteria for the Typical Tropical Class. In the paradigmatic TTS, optical thinning of the mixed layer as stratification intensifies will enhance primary production in the DCM, which should increase its biomass and create an increasingly effective trap for upwardly diffusing nutrients. Further, as the pycnocline and its resident DCM rise together, the depths of the chlorophyll and primary production maxima typically merge. Eventually, absorption of solar irradiance by pigments in the ascending DCM can cause increased heating of the upper pycnocline, resulting in augmented vertical mixing that diffuses the DCM (Lewis et al. 1983, Lewis 1987). This mechanism may create an upward limit on the primary production that can occur in a DCM in the most optically clear, stable, tropical open-ocean waters (Longhurst \& Harrison 1989).

Extrapolation of the local algorithm for primary production to large spatial scale is simplified for regions within the Typical Tropical Class. Here it is important to estimate accurately the spectral light reaching the DCM and to focus attention on describing the shape and light-photosynthesis curve for the chlorophyll peak, while a less rigorous approach may be taken in modeling the total primary production in the mixed layer. Given that the primary production maximum may reside in low-light, high-nutrient conditions within a Typical Tropical Province, an accurate value for the biomass-normalized initial slope may in such cases become the most important parameter for describing the light-photosynthesis curve. The northward spreading of a Typical Tropical Province across virtually all of the Arabian Sea south of $22^{\circ} \mathrm{N}$ (Fig. 3) is consistent with numerous and widespread in situ observations of a 2-layer euphotic zone consisting of oligotrophic surface waters over a DCM during this season (Yentsch 1965, Saijo 1973, Krey \& Babenerd 1976, Karabashev \& Solov'yev 1978, Banse 1987, Brock et al. 1991, Hay et al. 1992). Brock et al. (1993) used climatological mixed-layer depth, satellite ocean color 
observations, and a vertical chlorophyll profile observed by the RV 'Sonne' in the western Arabian Sea in May 1986 to parameterize the photosynthesis-irradiance model of Platt \& Sathyendranath (1988). During the spring intermonsoon in May, at this location $\left(14.36^{\circ} \mathrm{N}, 57.38^{\circ} \mathrm{E}\right)$ within the Typical Tropical Province, it was shown that the modeled primary production in the thermocline could exceed that in the mixed layer in the presence of a DCM.

Development of a TTS ecosystem during the spring intermonsoon was documented by Jochem et al. (1993) and Pollehne et al. (1993a), based on short-term Lagrangian drifter experiments. Near the Omani coast the phytoplankton community was observed to shift towards a more oligotrophic system, with a greater proportion of picoplankton and a subsurface chlorophyll maximum. In the central Arabian Sea, the 2-layer euphotic zone of the TTS was observed, incorporating a shallow 'closed' system of regenerated production with a predominance of picoplankton and only minor sedimentation losses, above a lower layer at the nutricline containing subsurface maxima in chlorophyll, algal biomass, and primary production. Jochem et al. (1993) attributed this deep algal biomass maximum to active growth, and observed higher sedimentation losses and more diatoms in the lower layer.

Pollehne et al. (1993b) confirmed the vertical zonation of phytoplankton by size in the central Arabian Sea during the intermonsoon season in May, with cyanobacteria dominating in the surface mixed layer above interlayered cyanobacteria-, coccolithophorid-, dinoflagellate-, and diatom-dominated layers in the DCMI. In accordance with the classic TTS, the highest rates of primary production were encountered in the nitricline at $50 \mathrm{~m}$ depth within the DCM at light levels above $1 \%$ of the surface irradiance. The ecological significance of the intermonsoon DCM in the central Arabian Sea is as a site of new production based on the upward import of nutrients from the nitricline, and as a source of export production (Pollehne et al. 1993b). We regard these in situ observations of the vertical biomass distribution, productivity regime, depth speciation, and size structure of the phytoplankton ecosystem as evidence for the ability of our biohydro-optical classification to infer the ecosystem mode of the open Arabian Sea during the spring intermonsoon.

\section{Barren Class}

The Barren Class is intended to identify the plankton ecosystem mode associated with the extremely oligotrophic conditions that prevail in the eastern basins of tropical oceans, or in regions undergoing deep winter mixing, where DCMs form due to the physiological adaptation of phytoplankton to extremely low light levels (Cullen 1982). This plankton ecosystem mode occurs on the western side of the tropical western Pacific, where the regional pycnocline is geostrophically deepened, driving a transition in the TTS DCM, which becomes diffuse as it deepens below the $1 \%$ light level (Saijo et al. 1969, Dandonneau 1979). A similar but more significant effect is seen at mid-latitudes following inhibition of algal growth by deep winter mixing. On the northern flank of the subtropical gyre in the north central Pacific the DCM traces the pycnocline to depths exceeding $100 \mathrm{~m}$ (Venrick et al. 1973), and even in summer the DCM typically occurs at, or below, the $1 \%$ isolume (Eppley et al. 1988). Similarly, in the central Indian Ocean, the DCM deepens southward to roughly $140 \mathrm{~m}$ at $25^{\circ} \mathrm{S}$ latitude (Saijo 1973), and in the northwest Atlantic a diffuse DCM exists below the deepened mixed layer in winter (Strass \& Woods 1988). In the best studied of these locations, the North Pacific, numerous previous studies strongly suggest that DCMs occurring at less than $1 \%$ of the surface irradiance are primarily due to increased cellular chlorophyll, rather than enhanced growth or variation in sinking rate as a function of density (Kiefer et al. 1976, Venrick 1982, 1988).

Although its evaluation lies outside the scope of this paper, as it only rarely occurs in the Arabian Sea, the Barren Class in our classification is intended to categorize the very unproductive ecosystem mode that occurs in these cases, where a layered euphotic zone consists of an oligotrophic mixed layer over a pycnocline in which cell division, grazing, and sinking rates are low, and that is illuminated at light levels that have been associated with DCMs due primarily to changes in the carbon-to-chlorophyll ratio as the resident cells become shade-adapted. Accordingly, the extrapolation of the local primary production algorithm to a large spatial scale (Platt et al. 1995) is relatively less important for Barren Provinces, as we can infer that total primary production is low, and new production is minimal within these regions.

\section{Mixed-Layer Bloom Class}

The Mixed-Layer Bloom Province in our northern Arabian Sea classification for the southwest monsoon corresponds to the ecosystem mode represented by tropical regions undergoing marginal or mid-ocean upwelling. In the northwest Arabian Sea at the onset of the southwest monsoon, and elsewhere in the tropical ocean at sites of equatorial divergence and over geostrophic domes, the TTS is displaced by the vertical motion of upwelled water, resulting in near-surface algal blooms (Longhurst \& Harrison 1989). Alterna- 
tively, we infer that the northern Arabian Sea MixedLayer Bloom Province that our March classification depicts is due to detrainment of the mixed layer as winds weaken and sea-surface temperature rises at the close of the northeast monsoon. Our March classification is in close accord with simulations obtained by McCreary et al. (1996), using a coupled physicalbiological model of the annual ecosystem cycle of the Arabian Sea.

In an analysis of about 4000 vertical pigment profiles, Morel \& Berthon (1989) recognized a systematic breakdown of the DCM between trophic categories ranging from very oligotrophic to highly eutrophic. As the TTS shifts towards eutrophication, the initially distinct DCM ascends and decreases in amplitude, until it vanishes in well-mixed eutrophic waters. Typically, the regenerative system of the upper TTS layer becomes indistinguishable from a mixed-layer bloom during the upward shift in the nutrient flux, previously the controlling factor for primary production above the mixed layer (Riegman et al. 1993). Larger algae, such as diatoms, which are too large for effective microzooplankton grazing (Raimbault et al. 1988, Banse 1992, Riegman et al. 1993), bloom in the nutrient-enriched mixed layer and initially experience loss through sedimentation. This export flux is due to the high primary production, new production, and f-ratios (Eppley \& Peterson 1979) typically observed for mixed-layer blooms.

Regional parameterization of the local primary production algorithm for primary production is greatly simplified within a Mixed-Layer Bloom Province. As there is no opportunity for significant primary production below the base of the mixed layer, there is no need to parameterize the algorithm for a DCM; rather, a homogeneous vertical phytoplankton pigment profile equal to that observed for the upper attenuation depth (Sathyendranath \& Platt 1989) is sufficient. Since the surface insolation is attenuated rapidly with depth, we suggest that a less rigorous method to estimate submarine light may be used. In view of the high vertical nutrient fluxes, we anticipate that it may be possible to estimate the parameters for the light-photosynthesis curve from the surface nitrate field (Platt et al. 1992), which is sometimes directly retrievable from satelliteobserved sea-surface temperature (Dugdale et al. 1989, Sathyendranath et al. 1991). We anticipate that within Mixed-Layer Bloom Provinces, where the bulk of global-ocean new production is likely to occur, a more simply parameterized analytic solution for vertically integrated photosynthesis by phytoplankton (Platt et al. 1990, Platt \& Sathyendranath 1993b) may be substituted as the local algorithm.

The appearance of a Mixed-Layer Bloom Province across virtually all of the western and northern Arabian Sea in August at the close of the southwest mon- soon (Fig. 4C) is consistent with numerous and widespread in situ observations of extreme monsoon-driven biological productivity. In summer, monsoonal upwelling (Bottero 1969, Smith \& Bottero 1977, Swallow 1984, Bauer et al. 1991) brings massive quantities of nutrient-rich water into the surface layer of the Arabian Sea (Ryther et al. 1966, Aruga 1973, Krey \& Babenerd 1973, McGill 1973, Wyrtki 1973, Swallow 1984, McCreary \& Kundu 1989), resulting in dramatically increased surface-layer chlorophyll concentrations, phytoplankton biomass, and primary production (Kabanova 1968, Krey \& Babenerd 1976, Banse 1987. Hitchcock \& Frazel 1989, Bauer et al. 1991, Brock et al. 1991, Brock \& McClain 1992), making the Arabian Sea one of the world's most productive ocean basins (Nair et al. 1989).

As is captured within our biohydro-optical classification for the months of the southwest monsoon (Fig. 4), in summer bath to the northwest and southeast of the climatological position of the Findlater Jet, the 2-layer TTS euphotic zone of the previous season is abolished, and its DCM erodes as a phytoplankton bloom unchecked by zooplankton grazing develops in the wellfertilized mixed layer (Banse 1994). Also in agreement with our definition of late summer provinces is the persistence of oligotrophic surface conditions and a DCM in the southeastern Arabian Sea observed by Yentsch (1965) east of $64^{\circ} \mathrm{E}$ in early September 1963, and east of $60^{\circ} \mathrm{E}$ in mid-September (Banse \& Anderson 1967). Typical tropical conditions were also reported late in the southwest monsoon in the southeastern Arabian Sea by Bauer et al. (1991) in August 1987 in the central Arabian Sea south of $12^{\circ} \mathrm{N}$, and from $20^{\circ} \mathrm{N}$ southward along $67^{\circ} \mathrm{E}$ during September 1986 (Mantoura et al. 1993, Owens et al. 1993).

Jochem et al. (1993) used a Lagrangian drifter during the late spring intermonsoon in 1987 to investigate the epipelagic system on the continental shelf off Pakistan and recorded the breakdown of the 2-layer system of the open, oligotrophic Arabian Sea during the spring intermonsoon. Although the vertical structure of physical, chemical, and biological variables was initially very similar to that observed in the central basin, upon inception of southwesterly monsoon winds in May and advection of the drifter shelfward, the nutrient flux to the lower euphotic layer was restricted, leading to the decay of the subsurface maxima in chlorophyll and primary production (Jochem et al. 1993). We suggest that the decay of the 2-layer euphotic zone observed by these researchers occurs across the Mixed-Layer Bloom Province depicted in our August biohydrooptical classification map (Fig. 4C), to be replaced by a region of greatly elevated mixed-layer carbon and nitrogen assimilation, and net production, with $f$-ratios approaching 0.9 (Owens et al. 1993). 


\section{Transitional Class}

The persistence of a widespread, contiguous Transitional Province in the northern and western Arabian Sea during the fall intermonsoon from October through December is anomalous, because this class normally marks the leading edges (Fig. 4C) or trailing borders (Fig. 3A) of advancing or senescing surfacelayer phytoplankton blooms. Its persistent occurrence over large regions is not expected, because although satellite-observed phytoplankton dominates mixedlayer light attenuation in this class, sufficient light reaches the nutricline to drive photosynthesis at depth and thereby trap upwardly diffusing nutrients and, presumably, maintain a DCM.

Given that the Arabian Sea experiences positive heat flux (Hastenrath \& Lamb 1979b), quiescent winds, and no active upwelling during the fall intermonsoon, the source of the nutrient flux necessary to maintain the elevated phytoplankton biomass observed by the satellite is not immediately obvious. One possible explanation is simply that our estimates of fall intermonsoon surface-layer chlorophyll are falsely high due to the presence of abundant colored dissolved organic material (CDOM) (Coble et al. in press) generated as the massive southwest monsoon phytoplankton bloom degenerates due to grazing and self shading (McCreary et al. 1996). The CZCS sensor was not able to distinguish viable phytoplankton from CDOM, but improved new-generation satellite-borne ocean color sensors, such as the Japanese Ocean Color Thermal Sensor (OCTS) launched in August 1996, the currently operating NASA Sea-Viewing Wide Field-of-View Sensor (SeaWiFS), and the Moderate Resolution Imaging Spectrometer (MODIS) planned for launch in the immediate future, will have this capability. This new capability to map synoptically the CDOM in the surface layer of the global ocean will be a powerful tool for study of the senescence of open-ocean phytoplankton blooms and may enable inferences to be made on the spatial and temporal structure of zooplankton blooms, because the main supply of dissolved organic matter (DOM) in the pelagic domain is most likely the feeding of zooplankton on phytoplankton and other organisms (Banse 1992).

In accord with Eppley et al. (1979), we prefer an alternative explanation for the persistence through the fall intermonsoon of an areally extensive Transitional Province in the northern and western Arabian Sea. Banse (1992) has shown that for areas of the open sea with pronounced seasonal blooms of phytoplankton, following the exhaustion of surface-layer macronutrients, concentrations of phytoplankton may remain unchanged for some time due to appreciable cell division rates that are controlled mainly by the rate of ammonium regeneration in the mixed layer. Once nitrate-driven new production forced by physical processes diminishes, the rate of nutrient regeneration and the phytoplankton cell division rate in the lightsaturated portion of the euphotic zone depend mainly upon zooplankton-mediated processes (Banse 1995). Zooplankton regenerate nutrients directly through feeding and also indirectly by releasing DOM which then serves as a substrate for bacteria. The pool of DOM taken up by the heterotrophic bacteria is subsequently degraded by both the bacteria themselves and the food chain of their associated predators (Azam et al. 1983), providing a second pathway for the regeneration of nutrients. To summarize, within nutrientdepleted, light-rich systems, it appears that through mediating nutrient regeneration, zooplankton physiology is responsible for the rate of phytoplankton production (Banse 1995).

We interpret the upper layer of the fall intermonsoon Transitional Province in the Arabian Sea as a special case of the shallow regenerative plankton ecosystem of oligotrophic ocean areas. During the fall intermonsoon, the physically determined rate of new production that must precede establishment of the regenerative system is extreme, and temporally shifted to the previous season, when a monsoon-driven massive summer phytoplankton bloom covers roughly the same region. Based on our biohydro-optical classification, we infer that, as has been observed for many other biogeochemical processes in the highly seasonal northwest Indian Ocean, in fall the rates of zooplankton-driven nutrient regeneration and recycled production, key processes in the upper layer of the TTS, reach extreme values. Evidence for this interpretation is provided by measurements of high rates of DOM generation within the summer algal bloom (Coble et al. unpubl.), and the observation of Watts \& Owens (in press) that ammonia was the preferred substrate for phytoplankton growth at stations in the northern Arabian Sea visited in November 1994.

Acknowledgements. The work presented in this paper was supported, in part, by the Office of Naval Research, the National Aeronautics and Space Administration, the European Space Agency, and the Department of Fisheries and Oceans, Canada. Additional support was provided by the Natural Sciences and Engineering Research Council through Operating Grants to S.S. and T.P., and a Visiting Fellowship to J.B. The authors thank the Nimbus Project at NASA/GSFC and the University of Miami for Coastal Zone Color Scanner Data Products. J.B. sincerely thanks S.S. and Alan Longhurst for stimulating discussion, patience and encouragement. This work was carried out as part of the Canadian contribution to the Global Ocean Flux Study. 


\section{LITERATURE CITED}

Antoine D, Morel A (1995) Algal pigment distribution and primary production in the eastern Mediterranean as derived from coastal zone color scanner observations. J Geophys Res 100(C8): 16193-16209

Aruga Y (1973) Primary production in the Indian Ocean. In Zeitzschel B (ed) The biology of the Indian Ocean Springer-Verlag, New York, p 127-130

Azam $F$, Fenchel T, Field JG, Gray JS, Meyer-Reil LA, Thingstad $F$ (1983) The ecological role of water-column microbes in the sea. Mar Ecol Prog Ser 10:257-263

Baker KS, Smith RC (1979) Quasi-inherent characteristics of the diffuse attenuation coefficient for irradiance. SPIE 208:60-63

Banse K (1987) Seasonality of phytoplankton chlorophyll in the central and northern Arabian Sea. Deep Sea Res $34(5 / 6): 713-723$

Banse K (1992) Grazing, temporal changes of phytoplankton concentrations, and the microbial loop in the open sea. In: Falkowski PG, Woodhead AD (eds) Primary productivity and biogeochemical cycles in the sea. Plenum Press, New York, p 409-440

Banse K (1994) On the coupling of hydrography, phytoplankton, zooplankton, and settling organic particles offshore in the Arabian Sea. Proc Indian Acad Sci 103(2):125-161

Banse K (1995) Zooplankton: pivotal role in the control of ocean production. J Mar Sci 52:265-277

Banse K, Anderson GC (1967) Computations of chlorophyll concentrations from spectrophotometric readings. Limnol Oceanogr 12:696-697

Bauer S, Hitchcock GL, Olson DB (1991) Influence of monsoonally-forced Ekman dynamics upon surface layer depth and plankton biomass distribution in the Arabian Sea. Deep Sea Res 38(5):531-553

Bird RE (1984) A simple, solar spectral model for directnormal and diffuse horizontal irradiance. Solar Energy 32 : 461-471

Bottero JS (1969) An analysis of upwelling off the southeast Arabian coast during the summer monsoon. MS thesis, Oregon State University, Corvallis

Brock JC, McClain CR (1992) Interannual variability in phytoplankton blooms observed in the northwestern Arabian Sea during the southwest monsoon. J Geophys Res $97(\mathrm{C} 1)$ 733-750

Brock JC, McClain CR, Hay WW (1992) A southwest monsoon hydrographic climatology of the northwestern Arabian Sea. J Geophys Res 97(C6):9455-9465

Brock JC, McClain CR, Luther ME, Hay WW (1991) The phytoplankton bloom in the northwestern Arabian Sea during the southwestern monsoon of 1979. J Geophys Res $96(C 11): 20623-20642$

Coble PG, Del Catillo C, Avril B (in press) Distribution and optical properties of CDOM in the Arabian Sea during the 1995 summer monsoon. Deep Sea Res

Brock JC, Sathyendranath S, Platt T (1993) Modeling the seasonality of subsurface light and primary production in the Arabian Sea. Mar Ecol Prog Ser 101:209-221

Cullen JJ (1982) The deep chlorophyll maximum: comparing vertical profiles of chlorophyll-a. Can J Fish Aquat Sci 39: 791-803

Cushing DH (1981) Temporal variability in production systems. In: Longhurst AR (ed) Analysis of marine ecosystems. Academic Press, London, p 443-472

Dandonneau Y (1979) Concentrations en chlorophylle dans le Pacifique tropical sud-ouest: comparaison avec d'autres aires oceaniques tropicales. Oceanol Acta 2:133-142
Dugdale RC, Goering JJ (1967) Uptake of new and regenerated forms of nitrogen in primary productivity. Limnol Oceanogr 12:196-206

Dugdale RC, Morel A, Bricaud A (1989) Modeling new production in upwelling centers: a case of modeling new production from remotely sensed temperature and color. J Geophys Res 94(C12):181.19-18132

Eppley RW, Peterson BJ (1979) Particulate organic flux and planktonic new production in the deep ocean. Nature 282: $677-680$

Eppley RW, Renger EH, Harrisan WG (1979) Nitrate and phytoplankton production in southern California waters. Limnol Oceanogr 24:483-494

Eppley RW, Renger EH, Venrick EL, Mullin MM (1973) A study of plankton dynamics and nutrient cycling in the central gyre of the north Pacific Ocean. Limnol Oceanogr 18(4):534-551

Eppley RW, Stewart E, Abbott MR, Heyman U (1985) Estimating ocean primary production from satellite chlorophyll. Introduction to regional differences and statistics for the Southern California Bight. J Plankton Res $7(1): 57-70$

Eppley RW, Swift E, Redalje DG, Landry MR, Haas LW (1988) Subsurface chlorophyll maximum in August-September 1985 in the CLIMAX area of the North Pacific. Mar Ecol Prog Ser 42:289-301

Feldman G, Kuring N, Ng C, Esaias W, McClain C, Elrod J, Maynard N, Endres D, Evans R, Brown J, Walsh S, Carle M, Podesta G (1989) Ocean-color: availability of the global data set. EOS Trans Am Geophys Union 70(23):634-635, $640-641$

Frost BW (1980) Grazing. In: Morris I (ed) The physiological ecology of phytoplankton. Studies in Ecology, Vol 7. University of California Press, Berkeley, p 465-491

Gieskes WWG, Kraay GW, Tussen SB (1978) Chlorophylls and their degradation products in the deep pigment maximum layer of the tropical North Atlantic. Neth J Sea Res 12:195-204

Gordon HR, McCluney WR (1975) Estimation of the depth of sunlight penetration in the sea for remote-sensing. Appl Optics 14(2):413-416

Hastenrath S, Greischar LL (1989) Climatic atlas of the Indian Ocean. Part III: Upper-ocean structure. University of Wisconsin Press, Madison

Hastenrath S, Lamb P (1979a) Climatic atlas of the Indian Ocean. Part I: Surface circulation and climate. University of Wisconsin Press, Madison

Hastenrath S, Lamb P (1979b) Climatic atlas of the Indian Ocean. Part II: The oceanic heat budget. University of Wisconsin Press, Madison

Hay BJ, McClain CR, Petzold M (1992) An assessment of the NIMBUS-7/CZCS calibration for May 1986 using satellite and in situ data from the Arabian Sea. Rem Sens Environ 43:35-46

Hayward TL, Venrick EL, MCGowan JA (1983) Environmental heterogeneity and plankton community structure in the central North Pacific. J Mar Res 41:711-729

Herbland A, Voituriez B (1977) Production primaire, nitrate et nitrite dans l'Atlantique tropical, 1-Distribution du nitrate et production primaire. Cah ORSTROM Oceanogr $15: 47-56$

Herbland A, Voituriez B (1979) Hydrological structure analysis for estimating the primary production in the tropical Atlantic Ocean. J Mar Res 37:87-101

Hitchcock GL, Frazel DW (1989) Primary productivity and pigment biomass in the Arabian Sea: R. R. S. Charles Darwin Cruise CD25. Nova University Oceanography Center Tech Rep NOVA-89-1, Dania, FL 
Hobson LA, Lorenzen CJ (1972) Relationships of chlorophyll maxima to density structure in the Atlantic Ocean and Gulf of Mexico. Deep Sea Res 19:297-306

Jerlov NG (1976) Marine optics. Elsevier Oceanography Series 14, Elsevier, New York

Jochem FJ, Pollehne $F_{1}$ Zeitzschel B (1993) Productivity regime and phytoplankton size structure in the Arabian Sea. Deep Sea Res 40(3):711-735

Kabanova YG (1968) Primary production in the northern part of the Indian Ocean. Oceanology 8(2):214

Karabashev GS, Solov'yev AN (1978) Relation between the fluorescence maxima of phytoplankton pigments and the location of the seasonal pycnocline. Oceanology 18(4): $468-471$

Kiefer DA, Olson RJ, Holm-Hansen O (1976) Another look at the nitrite and chlorophyll maximum in the Central North Pacific. Deep Sea Res 23:1199-1208

Krey J, Babenerd B (1973) Primary production in the Indian Ocean. In: Zeitzschel B (ed) The biology of the Indian Ocean. Springer-Verlag, New York, p 115-126

Krey J, Babenerd B (1976) Phytoplankton production atlas of the international Indian Ocean expedition. Institut für Meereskunde an der Universität Kiel

Levitus S (1982) Climatological atlas of the world ocean. NOAA Prof Pap 13:1-173

Lewis MR (1987) Phytoplankton and the thermal structure in the tropical ocean. Oceanol Acta 6:91-95

Lewis MR (1992) Satellite ocean color observations of global biogeochemical cycles. In: Falkowski PG, Woodhead AD (eds) Primary productivity and biogeochemical cycles in the sea. Plenum Press, New York, p 139-153

Lewis MR, Cullen JJ, Platt T (1983) Phytoplankton and thermal structure in the upper oceani consequences of nonuniformity in the chlorophyll profile. J Geophys Res 88 : $2565-2570$

Lewis MR, Kuring N (1988) Global patterns of ocean transparency: implications for the new production of the open ocean. J Geophys Res 93(C6):6847-6856

Longhurst AR (1981) Significance of spatial variability. In: Longhurst AR (ed) Analysis of marine ecosystems. Academic Press, London, p 415-441

Longhurst AR, Harrison WG (1989) The biological pump: profiles of plankton production and consumption in the upper ocean. Prog Oceanogr 22:47-123

Longhurst A, Sathyendranath S, Platt T, Caverhill C (1995) An estimate of global primary production in the ocean from satellite radiometer data. J Plankton Res 17(6):1245-1271

Longhurst A, Williams R (1979) Materials for plankton modelling: vertical distribution of Atlantic zooplankton in summer. J Plankton Res 1(1.):1-28

Mantoura RFC, Law CS, Owens NJP, Burkill PH, Woodward EMS, Howland RJM, Llewellyn CA (1993) Nutrient biogeochemical cycling in the northwestern Indian Ocean. Deep Sea Res II 40:651-671

Marra J, Wiebe PH, Bishop JKB, Stepien JC (1987) Primary production and grazing in the plankton of the Panama Bight. Bull Mar Sci 40:255-270

McCreary JP, Kohler KE, Hood RR, Olson DB (1996) A fourcomponent model of biological activity in the Arabian Sea. Prog Oceanogr 37:193-240

McCreary JP, Kundu PK (1989) A numerical investigation of sea surface temperature variability in the Arabian Sea. J Geophys Res 94(C11):16097-16114

McGill DA (1973) Light and nutrients in the Indian Ocean. In: Zeitzschel B (ed) The biology of the Indian Ocean. Springer-Verlag, New York, p 53-102

Mitchell BG, Brody EA, Yeh E, McClain C, Comiso J, May- nard NG (1991) Meridional zonation of the Barents Sea ecosystem inferred from satellite remote-sensing and in situ bio-optical observations. Polar Res 10(1):147-162

Morel A (1988) Optical modeling of the upper ocean in relation to its biogenous matter content (case I waters). J Geophys Res 93(C9):10749-10768

Morel A, Berthon J (1989) Surface pigments, algal biomass profiles, and potential production of the euphotic layer: relationships reinvestigated in view of remote-sensing applications. Limnol Oceanogr 34(8):1545-1562

Morel A, Prieur L (1977) Analysis of variations in ocean colour. Limnol Oceanogr 22:709-722

Mueller JL, Lange RE (1989) Bio-optical provinces of the Northeast Pacific Ocean: a provisional analysis. Limnol Oceanogr 34(8):1572-1586

Nair RR, Ittekkot V, Manganini SJ, Ramaswamy V, Haake B, Degens ET, Desai BN, Honjo S (1989) Increased particle flux to the deep ocean related to monsoons. Nature 338 : $749-751$

Owens NJ, Burkill PH, Mantoura RFC, Woodward EMS, Bellan IE, Aiken J, Howland RJM, Llewellyn CA (1993) Sizefractionated primary production and nitrogen assimilation in the northwestern Indian Ocean. Deep Sea Res II 40(3): $697-709$

Platt T, Caverhill C, Sathyendranath S (1991) Basin-scale estimates of oceanic primary production by remote-sensing: the north Atlantic. J Geophys Res 96(C8):15147-15159

Platt T, Sathyendranath S (1988) Oceanic primary production: estimation by remote-sensing at local and regional scales. Science $241: 1613-1620$

Platt T, Sathyendranath S (1993a) Comment on 'The remotesensing of ocean primary productivity: use of a new data compilation to test satellite algorithms' by William Balch et al. J Geophys Res 98(C9):16583-16584

Platt T, Sathyendranath S (1993b) Estimators of primary production for interpretation of remotely sensed data on ocean color. J Geophys Res 98(C8):14561-14576

Platt T, Sathyendranath $S$ (1995) Latitude as a factor in the calculation of primary production. In: Skjoldal HR, Hopkins C, Erikstad KE, Leinaas HP (eds) Ecology of fjords and coastal waters. Elsevier, New York, p 3-13

Platt T, Sathyendranath S, Longhurst A (1995) Remote-sensing of primary production in the ocean: promise and fulfilment. Phil Trans R Soc Lond 348(B):191-202

Platt T, Sathyendranath S, Ravindran P (1990) Primary production by phytoplankton: analytic solutions for daily rates per unit area of water surface. J Proc R Soc Lond B 241: $1.01-111$

Platt T, Sathyendranath S, Ulloa O, Harrison WG, Hoeffner N Goes J (1992) Nutrient control of phytoplankton photosynthesis in the western North Atlantic. Nature 356:229-231

Pollehne F, Klein B, Zeitzschel B (1993a) Low light adaptation and export production in the deep chlorophyll maximum layer in the northern Indian Ocean. Deep Sea Res II 40(3): $737-752$

Pollehne F, Zeitzschel B, Peinert R (1993b) Short-term sedimentation patterns in the northern Indian Ocean. Deep Sea Res II 40(3):821-831

Prieur L, Sathyendranath S (1981) An optical classification of coastal and oceanic waters based on the specific spectral absorption curves of phytoplankton pigments, dissolved organic matter, and other particulate materials. Limnol Oceanogr 26(4):671-689

Raimbault P, Rodier M, Taupier-Letage I (1988) Size fraction of phytoplankton in the Ligurian Sea and Algerian Basin (Mediterranean Sea): size distribution versus total concentration. Mar Microb Food Webs 3:1-7 
Riegman P, Kuipers BR, Noordeloos AAM, Witte HJ (1993) Sizedifferential control of phytoplankton and the structure of phytoplankton communities. Neth J Sea Res 31:255-265

Ryther JH, Hall JR, Pease AK, Bakun A, Jones MM (1966) Primary organic production in relation to the chemistry and hydrography of the western Indian Ocean. Limnol Oceanogr 11:371-380

Saijo Y (1973) The formation of the chlorophyll maximum in the Indian Ocean. In: Zeitzschel B (ed) The biology of the lndian Ocean. Springer-Verlag, New York, p 171-173

Saijo Y, lizuka S, Asaoka $\bigcirc$ (1969) Chlorophyll maxima in Kuroshio and adjacent area. Mar Biol 4:190-196

Sarmiento JL, Slater RD, Fasham MJR, Ducklow HW, Toggweiler JR, Evans GT (1993) A seasonal three-dimensional ecosystem model of nitrogen cycling in the North Atlantic euphotic zone. Global Biogeochem Cycles 7:417-450

Sathyendranath S, Platt T (1988) The spectral irradiance field at the surface and in the interior of the ocean: a model for applications in oceanography and remote-sensing. J Geophys Res 93(C8):9270-9280

Sathyendranath S, Platt T (1989) Computation of aquatic primary production: extended formalism to include effect of angular and spectral distribution of light. Limnol Oceanogr 34:188-198

Sathyendranath $S$, Platt $T$, Horne EP, Harrison WG, Ulloa $O$, Outerbridge R, Hoepffner $N$ (1991) Estimation of new production in the ocean by compound remote-sensing. Nature 353:129-133

Small LF, Knauer GA, Tuel MD (1987) The role of sinking fecal pellets in stratified euphotic zones. Deep Sea Res 30: $1199-1220$

Smith RC, Baker KS (1978a) The bio-optical state of ocean waters and remote-sensing. Limnol Oceanogr 23(2):247-258

Editorial responsibility: Otto Kinne (Editor), Oldendorf/Luhe, Germany
Smith RC, Baker KS (1978b) Optical classification of natural waters. Limnol Oceanogr 23(2):260-267

Smith RC, Baker KS (1981) Optical properties of the clearest natural waters (200-800 nm). Appl Optics 20(2):177-184

Smith RL, Bottero JS (1977) On upwelling in the Arabian Sea. In: Angel $M$ (ed) A voyage of discovery. Pergamon, New York, p 291-304

Strass V, Woods J D (1988) Horizontal and seasonal variation of density and chlorophyll profiles between the Azores and Greenland. In: Rothschild BJ (ed) Towards a theory of biological-physical interactions in the ocean. D Reidel, Dordrecht, p 113-136

Swallow JC (1984) Some aspects of the physical oceanography of the Indian Ocean. Deep Sea Res 31:639-650

Venrick EL (1982) Phytoplankton in an oligotrophic ocean, observations and questions. Ecol Monogr 52:129-154

Venrick EL (1988) The vertical distribution of chlorophyll and phytoplankton species in the North Pacific central environment. J Plankton Res 10:987-998

Venrick EL, McGowan JA, Mantyla AW (1973) Deep chlorophyll maximum of photosynthetic chlorophyll in the Pacific Ocean. Fish Bull US 71:41-52

Watts LJ, Owens LJP (in press) Nitrogen asimilation and the fratio in the northwestern Indian Ocean during an intermonsoon period. Deep Sea Res

Wyrtki K (1971) Oceanographic atlas of the International Indian Ocean Expedition. National Science Foundation, Washington, DC

Wyrtki K (1973) Physical oceanography in the Indian Ocean. In: Zeitzschel B (ed) The biology of the Indian Ocean. Springer-Verlag, New York, p 18-36

Yentsch CS (1965) Distribution of chlorophyll and phaeophytin in the open sea. Deep Sea Res 12:653-666

Submitted: February 3, 1997; Accepted: January 11, 1998 Proofs received from author(s): April 24, 1998 